\title{
IgG Subclasses and Antibodies to Group B Streptococci, Pneumococci, and Tetanus Toxoid in Preterm Neonates after Intravenous Infusion of Immunoglobulin to the Mothers
}

\author{
A. MORELL, D. SIDIROPOULOS, U. HERRMANN, K. K. CHRISTENSEN, P. CHRISTENSEN, \\ K. PRELLNER, H. FEY, AND F. SKVARIL \\ Institute for Clinical \& Experimental Cancer Research [A.M., F.S.], Department of Obstetrics and Gynecology \\ [D.S., U.H.], and Veterinary Bacteriological Institute [H.F.] of the University of Berne, Switzerland and \\ Departments of Medical Microbiology and Oto-Rhino-Laryngology [K.K.C., P.C., K.P.], University \\ of Lund, Sweden
}

\begin{abstract}
High doses of intravenous immunoglobulin were given to seven pregnant women between the 27 th and 36th wk of gestation who were at risk for preterm delivery. Determinations of IgG subclasses and of antibodies against group B streptococcal serotypes, pneumococcal polysaccharides, and tetanus toxoid were done in maternal serum before and after intravenous IgG infusion and after delivery in cord serum. Substantial transplacental passage of the infused material could be observed in five cases where delivery occurred at the 34th wh or later. After the 36th wk of gestation, IgG subclass and antibody concentrations in cord serum were increased up to the levels in the maternal serum. (Pediatr Res 20:933-936, 1986)
\end{abstract}

Abbreviation

IGIV, intravenous immunoglobulin

Preterm neonates are known to be highly susceptible to systemic bacterial infections (1). This increased risk is due in part to the immaturity of the immune system and to an incomplete transplacental transfer of protective $\mathrm{IgG}$ antibodies from the mother (2-7). Sidiropoulos et al. (8) have shown that the administration of IGIV in combination with antibiotics was effective in the treatment of neonatal sepsis, particularly in premature babies. As a consequence of this previous work, the question was asked whether perinatal or prenatal infection could be prevented by giving IGIV to pregnant women who were at risk for preterm delivery. As a first step, we studied the possibility of a transplacental passage of IGIV administered in the last trimenon of pregnancy. This report provides evidence that all four IgG subclasses and various specific antibodies present in the IGIV preparation are transferred from the mothers to the babies.

\section{PATIENTS}

The study included seven women between the 27th and the $36 \mathrm{th}$ wk of pregnancy who were at risk for preterm delivery with preterm labor, rupture of the membranes, or signs of chorioam-

Received February 23, 1986; accepted May 14, 1986.

Reprints A. Morell, M.D., Institute for Clinical and Experimental Cancer Research, University of Berne, Tiefenau-Hospital, CH-3004 Berne, Switzerland.

Supported by grants from the Swiss National Science Foundation and the Central Laboratory of the Swiss Red Cross Blood Transfusion Service. nionitis. The gestational age was assessed by serial ultrasonography and examination of the newborns. Informed consent was obtained from all women. Immunoglobulin applications consisted of intravenous infusions of $24 \mathrm{~g} \mathrm{IgG}$ (Sandoglobulin) at each of 5 consecutive days ( $6 \%$ solution in $0.9 \%$ saline, 10 drops/ min). In addition, the patients received the antibiotics amoxicillin (4 g/day) and clindamycin ( $1.8 \mathrm{~g} /$ day). Monitoring of pulse and blood pressure, cardiotocography, and clinical observation did not show any side effects attributable to IGIV in mothers and infants. Serum samples were obtained immediately before the first and after the last infusion. In three women in whom delivery was delayed for 8 -25 days after the last infusion, additional samples were taken at the time of birth. Cord blood samples were collected at delivery. The serum was kept at $-20^{\circ}$ $\mathrm{C}$ until assayed.

\section{METHODS}

$\operatorname{Ig} G$ subclasses. IgG subclass specific reagents were prepared by immunizing sheep with isolated myeloma proteins and quantitative determinations were done with a solid phase radioimmunoassay as described $(9,10)$. Binding inhibition curves were established using the WHO reference plasma $67 / 69$, the $\mathrm{IgG}$ subclass concentrations of which are known (9).

Determination of antibodies. Determinations of antibodies to surface antigens of group B streptococci (types Ia, Ib, II, and III), to pneumococcal polysaccharides (types $6 \mathrm{~A}, 19 \mathrm{~F}$, and $23 \mathrm{~F}$ ), and to tetanus toxoid were performed using radioimmunoassay and ELISA procedures are described in detail elsewhere $(11,12)$. Values were expressed in arbitrary units or in $\mathrm{IU} / \mathrm{ml}$.

\section{RESULTS}

Table 1 summarizes the results of $\mathrm{IgG}$ subclass determinations in maternal and cord blood samples of six pregnancies. In the patients $\mathrm{Ag}$ and $\mathrm{Th}$ who were delivered after $28 \mathrm{wk}$ of pregnancy, the IGIV infusions resulted in a pronounced increase of all four IgG subclass serum concentrations. In $\mathrm{Ag}$, cord blood subclass concentrations were lower than those observed in the maternal preinfusion sample and corresponded to values reported in the literature for that gestational age $(2,4,5)$. In Th, cord blood subclass levels were comparable to those observed in the maternal preinfusion sample and thus exceeded the expected values. In Ry and Le who were delivered at the 34th and 35th wk of gestation, the situation was complicated by long intervals between infusions and birth (11 and 25 days). Again, in the 
Table 1. Effect of high-dose immunoglobulin infusions on IgG subclass concentrations in maternal and cord serum

\begin{tabular}{|c|c|c|c|c|c|c|}
\hline \multirow{2}{*}{$\begin{array}{c}\text { Patients } \\
\text { (gestational } \\
\text { age at delivery) }\end{array}$} & \multirow{2}{*}{$\begin{array}{c}\text { Interval between } \\
5 \text { th infusion and } \\
\text { delivery }\end{array}$} & \multirow[b]{2}{*}{ Serum samples } & \multicolumn{4}{|c|}{ Concentrations of $\mathrm{IgG}$ subclasses ( $\mathrm{g} / \mathrm{liter}$ ) } \\
\hline & & & IgG1 & IgG2 & $\operatorname{lgG} 3$ & IgG4 \\
\hline $\mathrm{Ag}$ & 1 day & Maternal & & & & \\
\hline \multirow[t]{3}{*}{ (28th wk) } & & preinfusion & 6.6 & 3.3 & 0.6 & 0.3 \\
\hline & & postinfusion & 19.3 & 10.1 & 1.3 & 0.6 \\
\hline & & Cord blood & 4.5 & 0.9 & 0.2 & 0.1 \\
\hline Th & 1 day & Maternal & & & & \\
\hline \multirow[t]{3}{*}{ (28th wk) } & & preinfusion & 9.4 & 2.0 & 0.4 & 0.1 \\
\hline & & postinfusion & 14.7 & 5.1 & 0.9 & 0.2 \\
\hline & & Cord blood & 9.7 & 1.3 & 0.3 & 0.1 \\
\hline & 11 days & Maternal & & & & \\
\hline \multirow[t]{3}{*}{ (34th wk) } & & preinfusion & 8.0 & 0.8 & 0.5 & $<0.01$ \\
\hline & & at delivery & 11.9 & 4.6 & 0.7 & 0.7 \\
\hline & & Cord blood & 10.6 & 1.2 & 0.4 & 0.1 \\
\hline \multirow{5}{*}{$\begin{array}{l}\text { Le } \\
\text { (35th wk) }\end{array}$} & 25 days & Maternal & & & & \\
\hline & & preinfusion & 6.0 & 2.9 & 0.4 & 0.1 \\
\hline & & postinfusion & 15.9 & 8.4 & 1.0 & 0.4 \\
\hline & & at delivery & 7.5 & 5.1 & 0.4 & 0.2 \\
\hline & & Cord blood & 6.9 & 4.5 & 0.4 & 0.1 \\
\hline & 8 days & Maternal & & & & \\
\hline \multirow[t]{3}{*}{ (36th wk) } & & preinfusion & 7.4 & 2.6 & 0.3 & 0.1 \\
\hline & & at delivery & 17.1 & 8.4 & 1.0 & 0.3 \\
\hline & & Cord blood & 13.0 & 6.1 & 0.5 & 0.4 \\
\hline & 1 day & Maternal & & & & \\
\hline \multirow{3}{*}{ (37th wk) } & & preinfusion & 6.1 & 1.4 & 0.7 & 0.2 \\
\hline & & postinfusion & 16.0 & 7.4 & 1.1 & 0.5 \\
\hline & & Cord blood & 15.0 & 6.5 & 1.2 & 0.5 \\
\hline
\end{tabular}

maternal sera a marked increase of all subclass levels was achieved by the infusions of IGIV. In cord serum of Ry, the IgG1 level was higher than in the maternal preinfusion sample. In addition IgG4 could be demonstrated in the cord serum, whereas in maternal preinfusion serum of $R y$, this subclass was lacking. Similarly in samples from Le the IgG2 level was higher in cord than in preinfusion maternal serum. Patients $\mathrm{Cr}$ and $\mathrm{Sc}$ were delivered at the 36 th and 37 th wk of gestation. The IgG subclass concentrations in both cord sera were markedly higher than in the maternal preinfusion samples and approximated maternal values at the time of birth.

Antibody levels determined in maternal and cord serum samples are shown in Table 2. Immunoglobulin infusions were followed by an increase of all antibody concentrations in the maternal sera. In cord blood of the babies born after $28 \mathrm{wk}$ of pregnancy, antibody concentrations were lower than or similar to those in the maternal preinfusion samples. A different situation was noticed at the 34th and 35th wk of gestation, where cord serum antibody levels were generally higher than in corresponding maternal preinfusion samples but still below maternal values at the time of delivery. These data were corroborated by the findings in another pregnancy (Fig. 1): patient $\mathrm{Sb}$ had received three infusions of $24 \mathrm{~g}$ IGIV each at 3 consecutive days when spontaneous delivery took place in the 35 th wk of pregnancy. Even at this short interval between infusions and birth, cord serum levels of antibodies to group B streptococcal antigens exceeded preinfusion levels and approached values of the maternal sample at delivery. Finally, Table 2 shows the antibody concentrations observed in serum samples from $\mathrm{Cr}$ and $\mathrm{Sc}$ who were delivered after 36 and 37 wk of gestation. In both cord sera, antibody levels were close or identical to those in maternal serum at the time of birth and thus markedly higher than in the preinfusion maternal sera. Thus, the IgG subclass concentrations and the data from antibody determinations in maternal and cord sera are in agreement. Taken all together, the results provide evidence for significant transplacental passage of IGIV.

\section{DISCUSSION}

Maternal IgG is known to be transferred across the placenta, probably by an active transport mechanism involving Fc receptors for IgG molecules on the syncytiotrophoblast membrane $(13,14)$. Fetal serum levels of the four $\mathrm{IgG}$ subclasses increase proportionally with the gestational age (2-5). At the normal term of delivery cord serum levels of IgG and IgG subclasses are often found to be approximately $10 \%$ greater than the maternal levels $(2-5,15)$. A similar correlation to gestational age has been observed for levels of antibodies to group B streptococci $(6,7)$. Their presence in cord serum was shown to reduce the susceptibility to neontal group B streptococcal infections (16). To our knowledge, passage of other specific antibodies in relation to gestational age has not been reported. The pregnant women in the present study were at risk for preterm delivery and placental dysfunction could not be excluded. Nevertheless, the transport mechanism was still operative. Our results indicate that the placental Fc receptors and the subsequent steps involved in the transport across this biological barrier recognized and handled molecules of the infused immunoglobulin preparation such as endogenous IgG. This was demonstrated by the passage of all four IgG subclasses and of a number of antibodies specific for group B streptococcal and pneumococcal serotypes and for tetanus toxoid. As in physiological conditions, the extent of this transport depended on the gestational age. According to a limited passage at $28 \mathrm{wk}$, cord serum IgG subclass and antibody concentrations were lower than or similar to those in the maternal preinfusion samples. At $34 \mathrm{wk}$ and particularly at $36 \mathrm{wk}$ of gestation, the transport mechanism was working more effectively producing increments of IgG subclass and antibody concentrations in cord serum which were already visible 3 days after the start of the infusions. In view of the small number of patients studied, the data have to be interpreted with caution. However, there is evidence from this pilot study that high doses of IGIV given to mothers after approximately $34 \mathrm{wk}$ of gestation could 
Table 2. Effect of high-dose immunoglobulin infusions on antibody levels in maternal and cord serum

\begin{tabular}{|c|c|c|c|c|c|c|c|c|c|c|}
\hline \multirow{2}{*}{$\begin{array}{c}\text { Patients } \\
\text { (gestational } \\
\text { age at delivery) }\end{array}$} & \multirow[b]{2}{*}{ Serum samples } & \multicolumn{4}{|c|}{ Group B streptococcal antigens } & \multicolumn{4}{|c|}{ Pneumococcal antigens } & \multirow{2}{*}{$\begin{array}{l}\text { Tetanus toxoid } \\
\text { (IU/ml) }\end{array}$} \\
\hline & & Ia & $\mathrm{Ib}$ & II & III & 3 & $6 \mathrm{~A}$ & $19 \mathrm{~F}$ & $23 \mathrm{~F}$ & \\
\hline & Maternal & & & & & & & & & \\
\hline \multirow[t]{3}{*}{ (28th wk) } & preinfusion & $910^{*}$ & 1170 & 660 & 760 & & $180^{*}$ & 290 & 140 & 1.3 \\
\hline & postinfusion & 2170 & 2150 & 1140 & 1820 & & 330 & 440 & 310 & 6.8 \\
\hline & Cord blood & 800 & 430 & 460 & 580 & & 160 & 210 & 70 & $<0.8$ \\
\hline Th & Maternal & & & & & & & & & \\
\hline \multirow[t]{3}{*}{ (28th wk) } & preinfusion & 1300 & 1790 & 610 & 1060 & 10 & 90 & 280 & 120 & 1.4 \\
\hline & postinfusion & 2210 & 2560 & 1170 & 1570 & 70 & 190 & 440 & 270 & 5.5 \\
\hline & Cord blood & 1200 & 1360 & 720 & 1130 & 10 & 120 & 300 & 110 & 1.2 \\
\hline Ry & Maternal & & & & & & & & & \\
\hline \multirow[t]{3}{*}{ (34th wk) } & preinfusion & 540 & 1230 & 410 & 550 & 30 & 50 & 70 & 20 & 2.7 \\
\hline & at delivery & 1770 & 2220 & 880 & 1280 & 150 & 210 & 390 & 220 & 6.7 \\
\hline & Cord blood & 1170 & 1540 & 820 & 840 & 80 & 150 & 210 & 120 & 6.8 \\
\hline \multirow{5}{*}{$\begin{array}{l}\text { Le } \\
\text { (35th wk) }\end{array}$} & Maternal & & & & & & & & & \\
\hline & preinfusion & 530 & 1410 & 540 & 500 & & 80 & 100 & 50 & $<0.8$ \\
\hline & postinfusion & 2300 & 2110 & 1190 & 1740 & & 250 & 330 & 230 & 7.8 \\
\hline & at delivery & 1310 & 1900 & 820 & 1200 & & 200 & 270 & 150 & 2.9 \\
\hline & Cord blood & 1150 & 1840 & 680 & 920 & & 140 & 200 & 130 & 2.0 \\
\hline $\mathrm{Cr}$ & Maternal & & & & & & & & & \\
\hline \multirow[t]{3}{*}{ (36th wk) } & preinfusion & 930 & 1190 & 580 & 660 & 10 & 150 & 400 & 150 & $<0.8$ \\
\hline & at delivery & 2230 & 2080 & 900 & 1500 & 140 & 230 & 520 & 290 & 7.0 \\
\hline & Cord blood & 2000 & 1790 & 870 & 1400 & 110 & 230 & 450 & 330 & 4.8 \\
\hline $\mathrm{Sc}$ & Maternal & & & & & & & & & \\
\hline \multirow[t]{3}{*}{ (37th wk) } & preinfusion & 1010 & 1020 & 530 & 1050 & 30 & 120 & 240 & 80 & $<0.8$ \\
\hline & postinfusion & 2490 & 2080 & 1070 & 1760 & 140 & 240 & 550 & 100 & 7.3 \\
\hline & Cord blood & 2240 & 2460 & 1210 & 1660 & 300 & 250 & 430 & 270 & 5.9 \\
\hline
\end{tabular}

* Values are expressed in arbitrary units.

maternal serum

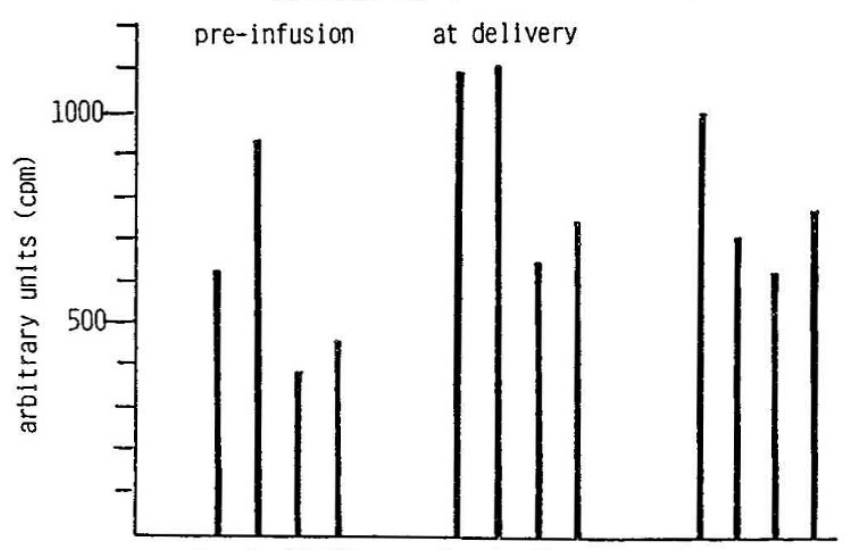

Ia Ib II III Ia Ib II III Ia Ib II III

types of antibodies to GBS

Fig. 1. Concentrations of antibodies to group B streptococci of types Ia, Ib, II, and III (arbitrary units in cpm) in serum samples from patient Sb. Delivery was in the 35 th wk of gestation after three infusions of a total of $72 \mathrm{~g}$ Sandoglobulin. The infusions resulted in an increase of all four antibody levels in maternal serum. Note that anti-Ia, anti-II, and anti-III concentrations in cord serum were markedly higher than in the maternal preinfusion sample taken 3 days before delivery.

compensate for the physiological antibody deficiency in fetuses of that age. The possible clinical significance of this observation remains to be tested.

Polyspecific immunoglobulin preparations for intravenous use differ in their biological properties according to the manufacturing procedures which sometimes include enzymatic and chemical modifications of the Fc portion of the IgG molecules (17). One would assume that these procedures had an influence on transplacental passage. Recently, a modified IgG preparation used for replacement therapy in two- antibody-deficient mothers was shown to cross the placental barrier (18). Apparently, treatment of $\mathrm{IgG}$ molecules of this preparation with reducing and alkylating agents did not abolish this biological property. The existence of quantitative differences between IGIV preparations in this respect will have to be demonstrated in future studies.

Acknowledgments. Purified antigen from pneumococci types $6 \mathrm{~A}, 19 \mathrm{~F}$, and $23 \mathrm{~F}$ were kindly supplied by Merck, Sharp \& Dohme, West Point, PA. The rabbit antipneumococcal antibody preparations used in the test were a gift from Dr. J. Henrichsen, Statens Seruminstitut, Copenhagen, Denmark.

\section{REFERENCES}

1. Cashore WJ, Stern L 1984 Neonatal problems of the preterm baby. Clinics Obstet Gynecol 11:391-414

2. Morell A, Skvaril F, van Loghem E. Kleemola M 1971 Human IgG subclasses in maternal and fetal serum. Vox Sang 21:481-492

3. Pitcher-Wilmott RW, Hindocha P, Woods CBS 1980 The placental transfer of IgG subclasses in human pregnancy. Clin Exp Immunol 41:303-308

4. Oxelius VA, Svenningson NW $1984 \mathrm{IgG}$ subclass concentrations in preterm neonates. Acta Paediatr Scand 73:626-631

5. Evans HE, Akpato SO, Glass L 1971 Serum immunoglobulin levels in premature and full term infants. Am J Clin Pathol 56:416-418

6. Boyer KM, Papierniak CK, Gadzala RN, Parvin JD, Gotoff SP 1984 Transplacental passage of $\mathrm{IgG}$ antibody to group $\mathrm{B}$ streptococcus serotype Ia. $\mathrm{J}$ Pediatr 104:618-620

7. Christensen KK, Christensen P, Duc G, Höger P, Kind C, Matsunaga T, Müller B, Seger RA 1984 Correlation between serum antibody-levels against group B streptococci and gestational age in newborns. Eur J Pediatr 142:8688

8. Sidiropoulos D, Boehme U, von Muralt G, Morell A, Barandun S 198 Immunoglobulinsubstitution bei der Behandlung der neonatalen Sepsis. Schweiz Med Wochenschr 111:1649-1655

9. Skvaril F, Roth-Wicky B, Barandun S $1980 \mathrm{IgG}$ subclasses in human $\gamma$ globulin preparations for intravenous use and their reactivity with Staphy 
lococcus protein A. Vox Sang 38:147-155

10. Morell A, Skvaril F, Steinberg AG, van Loghem E, Terry WD 1972 Correlations between the concentrations of the four subclasses of $\mathrm{IgG}$ and $\mathrm{Gm}$ allotypes in normal human sera. J Immunol 108:195-206

11. Christensen KK, Christensen P, Dahlander K, Faxelius G, Jacobson B, Svenningsen N 1980 Quantitation of serum antibodies to surface antigens of group B streptococci types Ia, Ib, and III: low antibody levels in mothers of neonatally infected infants. Scand J Infect Dis 12:105-110

12. Stiffler-Rosenberg G, Fey H 1977 Messung von Tetanus Antitoxin mit dem Enzyme-linked immunosorbent assay (ELISA). Schweiz Med Wochenschr 107:1101-1103

13. Johnson PM. Brown PH 1981 Fc $\gamma$ receptors in the human placenta. Placenta 2:355-398

14. Gitlin D 1971 Development and metabolism of immune globulins. In: Kagan
BM, Stiehm ER (eds) Immunologic Incompetence. Year Book Medical Publishers, Chicago, pp 3-13

15. Kohler PF, Farr RS 1966 Elevation of cord over maternal IgG immunoglobulin. Evidence for an active placental IgG transport. Nature 210:1070-1071

16. Baker CJ, Kaspar DL 1976 Correlation of maternal antibody deficiency with susceptibility to neonatal group B streptococcal infection. N Engl $\mathbf{J}$ Med 294:753-756

17. Römer J, Morgenthaler JJ, Scherz R, Skvaril F 1982 Characterization of various immunoglobulin preparations for intravenous application. Vox Sang 42:62-80

18. Sorensen RU, Tomford JW, Gyves MT, Judge NE, Polmar SH 1984 Use of intravenous immune globulin in pregnant women with common variable hypogammaglobulinemia. Am J Med 76:73-77 